The University of San Francisco

USF Scholarship: a digital repository @ Gleeson Library |

Geschke Center

History

College of Arts and Sciences

2012

\title{
Visions of Juliana: A Portuguese Woman at the Court of the Mughals
}

Taymiya R. Zaman

University of San Francisco, trzaman@usfca.edu

Follow this and additional works at: http://repository.usfca.edu/hist

Part of the History Commons

\section{Recommended Citation}

Zaman, T. R. (2012). Visions of Juliana: A Portuguese Woman at the Court of the Mughals. Journal Of World History, (4), 761. http://dx.doi.org/10.1353/jwh.2012.0136

This Article is brought to you for free and open access by the College of Arts and Sciences at USF Scholarship: a digital repository @ Gleeson Library | Geschke Center. It has been accepted for inclusion in History by an authorized administrator of USF Scholarship: a digital repository @ Gleeson Library | Geschke Center. For more information, please contact repository@usfca.edu. 


\title{
Visions of Juliana: A Portuguese Woman at the Court of the Mughals*
}

\author{
TAYMIYA R. ZAMAN \\ University of San Francisco
}

HE seventeenth and eighteenth centuries saw Portuguese colo-
nial holdings (Estado da India) faltering in India because of com-
petitors such as the English, French, and Dutch. Thoughts of quitting
Goa altogether appear in Portuguese correspondence, as do reports of
attacks at sea that harm colonial trade. ${ }^{1}$ The eighteenth century also
saw the Mughal Empire ( $1526-1857$ ) balanced precariously around the
possibility of collapse, a consequence of the rise of successor states and
the political aspirations of European trading companies. In such a land-
scape, one Juliana Dias da Costa (d. I 734), a Portuguese woman who
held enormous power and influence at the court of the Mughal king
Bahadur Shah I (d. I 7 I 2 ), attracted the attention of many.
Juliana gained the patronage of the Estado, with whom she kept
up a steady correspondence from I 707 to I 7 I 5 , secured an audience
with the king for the Dutch East India Company in I 7 I I, and drew the
attention of the Italian Jesuit Ippolito Desideri (d. I 733 ), who visited

* For their help with this project, I am grateful to Kecia Ali, Reihaneh Fakourfar, Beverly Hallam, Javed Jabbar, Bilkees Latif, Shahryar Khan, Miguel Lourerio, Kathy Nasstrom, Moeen Nizami, Katrina Olds, and the late Jerry Bentley. Beverly Hallam was especially helpful in sharing her research with me, and Kecia Ali's assistance with Gracias was invaluable, as were the suggestions of Katrina Olds. All errors in this article are my responsibility alone.

${ }^{1}$ G. V. Scammmell, "The Pillars of Empire: Indigenous Assistance and the Survival of the 'Estado da India' c. I600-I 700," Modern Asian Studies 22, no. 3 (I988): 473-489. 
India in $\mathrm{I} 7 \mathrm{I} 4 .^{2}$ Desideri reported from hearsay that Juliana had brought Bahadur Shah I to the brink of baptism, so impressed was he with her Christian piety and ability to perform miracles. ${ }^{3}$ Juliana's fame, which was a combination of her piety and political power, continued after her death. She is the subject of an unpublished biography penned in Persian by a Frenchman named Gaston Bruit in 1752 , who may have been linked, by marriage, to her family, and who praises her piety in a manner similar to Desideri. ${ }^{4}$ She also appears in a nineteenth-century account in French by Colonel Jean-Baptiste Gentil, who was Bruit's patron, and married to Juliana's grandniece Teresa Velho. Gentil draws upon earlier accounts of Juliana to put forth in a dramatic manner her extraordinary political prowess and her spiritual conquest of a Muslim king. ${ }^{5}$ These visions of Juliana are informed by the interests of those writing about her, which means that actual facts about her life are often eclipsed by tales of her power. Jesuit sources, for instance, depict Juliana as a proxy for their spiritual mission in India, just as Portuguese sources portray her as a proxy for their political aspirations during a time when their power is waning. Men such as Gentil and Bruit portray Juliana as embodying a crucial link between Europe and India; she fits well into a landscape in which European travelers, missionaries, and merchants moved easily across different worlds and formed strategic alliances depending on opportunity and circumstance. As a European woman able to influence the Mughal king, and valuable to both the Mughals and the Portuguese, Juliana occupies a position that is similar to that of men such as Gentil, who had served both the Mughals and the French.

Under formal British rule, following the dissolution of the Mughal Empire in 1857 , Juliana's descendants became the subject of much

${ }^{2}$ For Juliana's dealings with the Estado, see J. A. Ismael Gracias, Uma Dona Portuguesa na Corte do Grao-Mogol (Nova Goa, I907).

${ }^{3}$ For a partial account of Juliana's reception of the Dutch embassy, see Rev. H. Hosten SJ, "The Family of Lady Juliana Dias da Costa (1658-1 732)," Journal of the Punjab Historical Society 7 (I9I8): 39-49. An account of Juliana's reception of the Dutch embassy can also be found in William Irvine, The Later Mughals I 707-I739, ed. Jadunath Sarkar (Lahore: Sang-i-Meel, 2007), pp. I33-I 40. For Desideri's account, see Ippolito Desideri, An Account of Tibet: The Travels of Ippolito Desideri of Pistoia, S.J. I 7 I 2-I 727 , ed. Filippo de Filippi, The Broadway Travellers Series, ed. Sir E. Dennison Ross and Eileen Power (London: Routledge, I932; repr., Taipei: Ch'eng Wen Publishing Company, I97I), pp. 64-66. My page numbers, unless indicated otherwise, refer to this edition.

${ }^{4}$ See Gaston Bruit, Ahvāl-i Bibi Juliana. British Library MS: Add. I4,374.

5 See Jean-Baptiste Joseph Gentil, Memoires sur l'Hindoustan, ou Empire Mogul (Paris, I822). For spiritual conquest in Jesuit colonial literature, see Ines G. Zupanov, "The Prophetic and the Miraculous in Portuguese Asia: A Hagiograhical View of Colonial Culture," in Sinners and Saints: The Successors of Vasco da Gama, ed. Sanjay Subrahmanyam (New York: Oxford University Press, I995), pp. I35-I6I. 
scholarly debate because they were a curiosity from a century in which several Europeans continued to hold ties to both Europe and India. British sources from this time interrogate the claims of Juliana's descendants to lands once held by her, and Sir Edward Maclagan (d. I952), the British governor of Punjab and the author of a work titled "The Jesuits and the Great Mogul," brings together several sources about Juliana to historicize the lives of her descendants and to interrogate their claims. ${ }^{6}$ His lengthy discussion of Juliana includes an investigation into legendary tales about her life; this implies that these stories were in circulation among Europeans in India, quite possibly because they had been put forth by those claiming to be her descendants. Moreover, stories about Juliana might have circulated because there was an audience for them in the nineteenth and early twentieth centuries among Maclagan's contemporaries, namely scholars of Jesuit and Christian history, or government officials who had succeeded the Mughals in ruling India.

The place held by Juliana in the imagination of Europeans in British India and the tangible link to the past embodied by Juliana's descendants also fueled visions of a Juliana that had in them elements of fiction, including unverifiable tales of capture and escape and highly fantastical claims about her family. However, after the collapse of British power in 1947 and the loss of lands by her descendants, Juliana and her descendants abruptly disappear from scholarly inquiry. Juliana appears again in our century through investigative research on the part of Beverly Hallam, one of her descendants in London, and through a fictionalized account of her life by the Indian author Bilkees Latif. ${ }^{7}$ In Latif's account, Juliana is emblematic of a lost Indian past in which people could claim multiple religious and ethnic allegiances. Affected by religious violence in India and by the admiration for Juliana she finds in sources such as Gentil, Desideri, and Maclagan, the author imagines Juliana as representing better times. Meanwhile, Beverly Hallam's research draws upon the same body of sources, but also focuses on archival sources in the British Library that allow her to trace her family's descent from Juliana.

${ }^{6}$ See Sir Edward Maclagan, The Jesuits and the Great Mogul (London: Burns Oates and Washbourne, I932; repr., Haryana, India: Vipin Jain for Vintage Books, I990), pp. I65-168, I $8 \mathrm{I}-\mathrm{I} 89$.

7 See Beverly Hallam, "On the Trail of Manuel D'Eremao and Juliana Dias da Costa: A Quest to Verify Oral Tradition through the India Office Records," Journal of the Families of British India Society I 7 (2007): 24-31. See also Bilkees I. Latif, Forgotten (New Delhi: Penguin Books, 2010), pp. 3-63. 
Together, extant sources about Juliana's life traverse six languages, three centuries, several personal and political purposes, and a multiplicity of genres. This means that a study of Juliana raises numerous challenges. First, while the historical figure Juliana Dias da Costa clearly existed, facts about her, including her date of birth and parentage, remain a mystery, as do the circumstances that brought her to the Mughal court. Her parents could have come to the Mughal court as prisoners captured during the Mughal raid on Hugli in Portuguese India in I632. The raid, ordered by the Mughal emperor Shah Jahan (d. I666), was a response to Portuguese attacks on Mughal ships. Her parents could also have fled to the Mughal court in I663 from the city of Cochin, which the Dutch seized from the Portuguese. Alternatively, she could have come to the court of Shah Jahan's son Aurangzeb (d. I 707) as the wife of a Portuguese surgeon sent there by officials of the Estado da India. The sources seem to agree that she died around I 734, though her age at death is uncertain.

Second, the sensibilities through which we learn of Juliana and the political purposes they serve themselves require contextualization; a Jesuit traveler writing about her during her lifetime will have a perspective that differs considerably from a British government official attempting to ascertain whether her descendants' claims to land are in fact genuine. This article examines extant sources on Juliana in the light of these challenges and of questions that the sources raise. What, for instance, was the nature of Juliana's power at the Mughal court? How was her power understood by her contemporaries and by those penning accounts of her after her death? Is it possible to extricate the historical person Juliana Dias da Costa from the lore that comes to surround her in the tales told by her descendants in the nineteenth century, and what purposes does such lore serve? This article concludes with my own attempt to track down a descendant of Juliana's in Pakistan and illustrates how modern linguistic, ethnic, and national boundaries make the legacy of Juliana difficult to map. Finally, this article shows how a historical figure from Mughal India came to be a canvas onto which several empires and individuals painted their political aspirations and understandings of power.

\section{Conquering a King, Serving an Empire}

For Ippolito Desideri, who arrived in Delhi in I 7 I4, Juliana marked a successful Christian presence in a foreign land. He wrote that despite the reluctance of "Muhammadans" to convert, the Jesuits had success- 
fully baptized several pagans, and that many Europeans held high positions at the court of the king. ${ }^{8}$ Of these Europeans, "Donna Giuliana Diaz da Costa" was the "support and ornament of our Holy Faith in the Empire." Endowed from childhood with eloquence, wisdom, and knowledge of medicine, Juliana was entrusted with the education of several royal children, along with "intricate business, precious treasures, and important family secrets." She hoisted the standard of the holy cross and she had brought the emperor Bahadur Shah I to everything short of baptism; he would kneel before Jesus in prayer and send blessings to churches, and it was rumored that he had become a Christian on his deathbed at the hands of Juliana. "Indeed," writes Desideri, "his mother, who by the intercession of St. John the Baptist, had miraculously conceived this son, named him Yahya, which is St. John the Baptist in Arabic." 10

While patronage of Christian rituals, art, and institutions was not uncommon in the courts of Mughal kings, Juliana is seen by Desideri as "ours," a claim of ownership that marks Juliana as representing both a Christian and a European presence close to the heart of Mughal power. Desideri is likely to have heard stories about Juliana from Jesuit missions and believes that Juliana's parents came to the Mughal court in I663, following the Dutch capture of Cochin. At the Mughal court, writes Desideri, Juliana rose to prominence and aided Jesuit missions through her influence on the king. Desideri writes that on Palm Sunday, Bahadur Shah I would send for a consecrated palm branch, which he would keep in his room for the rest of the year. When a fire broke out in his palace, reports Desideri, Juliana threw such a branch into the flames, and all watched rapt as the fire subsided. Desideri goes to mention her aid to his mission, and writes:

Our Father General has several times expressed his gratitude to her, and when I left, Rome named her a member of our Confraternity, thus granting her a share of the Indulgences enjoyed by us. In the same year, the King of Portugal sent her various presents and a magnificent letter, thanking her for her services to the Court of Mogol, to Christianity, Portugal, the States of Goa, and the part of India subject to his crown. The Dutch East India Company also acknowledged their obli-

\footnotetext{
${ }^{8}$ Desideri, Account of Tibet, p. 64.

9 Ibid., p. 65.

10 Ibid., p. 66.
} 
gations to Donna Giuliana. Indeed, her name is known and celebrated throughout this vast Empire. ${ }^{11}$

Jesuit missions to India had a long history: the first mission came to India shortly after the founding of the Society of Jesus in I540, and Mughal and Jesuit sources report the presence of Jesuits at the courts of the Mughal kings Akbar and Jahangir. The success of these missions was debatable as Mughal willingness to engage with Jesuit ideas was not indicative of imminent conversion. At the same time, the possibility of converting a Mughal king and consequently his subjects figured heavily in Jesuit imagination..$^{12}$ In his account of Juliana, Desideri is flirting with this possibility by pointing to Juliana's position in the Mughal household as the custodian of family secrets and the teacher of royal children, and as exercising an influence on the king that benefitted Jesuit missions and Christians in general. The presence of powerful European men at the Mughal court and of one powerful European woman (recognized as such by the king of Portugal himself) in the Mughal household allows Desideri to imply that both imperial and spiritual missions for conquest are enjoying tremendous success.

The rumors about Bahadur Shah's conversion on his deathbed are impossible to corroborate, but their presence in Desideri's account points to the circulation of tales based partly on truth, namely Juliana's Christian faith and proclivity for helping Jesuit missions (as later sources will also show) but partly on wishful thinking and embellishment. Francois Valentyn's Oud en Niew Oost-Indien ( I 726), a record of the Dutch Embassy to India under Johan Josua Ketelaar, mentions Juliana in similarly glowing terms. Ketelaar arrived in Lahore in I 7 I I, the last year of Bahadur Shah I's reign, and wrote that the king was a friend to the Christians because of her influence. She arranged for an interview for Ketelaar, inspected the presents he had brought for Bahadur Shah I to make sure they were appropriate, invited his musicians to serenade the king and princes, and took Ketelaar's entourage to see the Shalimar gardens. When Bahadur Shah I died, Juliana warned Ketelaar to be on guard against plunderers, and continued to ensure the safety of his embassy.

11 Ibid., pp. 66-67.

12 See Muzaffar Alam and Sanjay Subrahmanyam, "Catholics and Muslims in the Court of Jahangir (I608-1630)," in Writing the Mughal World: Studies in Political Culture, eds. Muzaffar Alam and Sanjay Subrahmanyam (Delhi: Permanent Black, 20 I I ), pp. 249-3 Io. I derive my point about Jesuit imagination from this essay. 
According to Valentyn, Juliana took no presents from anyone, helped everyone equally, and was loved by all. In battle, she prophesied victory for Bahadur Shah I against his brother because the prayers of all the Christians were with him, and encouraged him to make one last stand while riding beside him on an elephant; as always, Juliana carried red standards with white crosses on them. Valentyn refers to her as the "oracle of the emperor" and mentions that her father was a merchant called Augustinho Dias da Costa who was in Cochin when the Dutch plundered it. He then went to Goa and Bengal, where Juliana was born, and at Agra he became a mansabdār (ranked official) and surgeon to Bahadur Shah I when he was still a prince. When the prince was in captivity after rebelling against his father Aurangzeb, Juliana served him faithfully. ${ }^{13}$ Valentyn's account of Ketelaar's embassy may have served as one of the sources for Desideri, given that Ketelaar arrived in India three years before Desideri, when Bahadur Shah I was still alive. The two accounts seem to agree about her parentage, her closeness to the king, and her piety, which allowed her to perform remarkable feats. Reading these two sources together shows the place that Juliana held in European and Jesuit imagination during her life, while pointing to the actual power held by her at the court of the king.

Juliana does in fact appear to have helped everyone equally, given that the Portuguese, despite being in competition with the Dutch, seem to have benefitted enormously from her power in court. Ismail Gracias has drawn upon the documents of the archive of the General Secretariat of the Estado da India to depict how, in "a strange and faraway place," Juliana worked with zealous dedication for the interest of her country [patria]. Gracias writes that "her strong feelings towards the motherland were skillfully energized by an illustrious viceroy, whose government stood out as a blue and starry stretch over the dark sky of the eighteenth century." While Gracias writes that information about this great lady is scant, something of her life has been salvaged from being forgotten, and refers to the Gospel: "Gather up the fragments that are left, lest they be lost" (John 6:12).14

Gracias's book, published in 1907, is literally a gathering of many fragments from the past. The first section of his book consists of what he calls historical sketches of the political and diplomatic relations

${ }^{13}$ I draw my summary of events here from Hosten, "Family of Lady Juliana Dias da Costa," pp. 39-49, and Irvine, Later Mughals, pp. I33-I 40.

${ }^{14}$ Gracias, Uma Dona Portuguesa na Corte do Grao-Mogol , p. 2. 
between the Estado and the Mughal court. These sketches begin with the reigns of Babur and Humayun and Akbar (1526-1605), and conclude with the reign of Bahadur Shah I, in which we see Juliana's rise to prominence. Gracias writes that these sketches are meant to preface a collection of correspondences of the Estado that took place from i 7 Io to I 7 I 9 and are important for the reader to gain a good understanding of the Mughal Empire and the Estado. ${ }^{15}$ The correspondences, which constitute a separate section, include letters from the viceroys of Portuguese India to King João V ( I 706-I 750), which report on economic and political affairs in India. They also include one letter from Juliana herself, written in Persian in I 7 I I (and translated to Portuguese), in which she invokes the name of Jesus and the grace of the Holy Spirit, prays for the glory of João V's throne, and acknowledges presents exchanged between the Estado and the Mughal court. ${ }^{16}$ These presents are probably those referred to by Desideri in his visit to India three years after she wrote this letter.

The records collected by Gracias imply that in the minds of the officials of the Estado, Juliana was a Portuguese woman strategically placed at court for the purpose of acting in their interests; nothing is said of the circumstances that brought her parents to the Mughal court. Instead, in a letter to João V, Vasco Fernandes writes that Juliana came to the Mughal court because she was married to a Portuguese surgeon who had entered the service of the king and who had been sent to court by the Portuguese viceroy, Francisco de Távora, Conde de Alvor ( $168 \mathrm{I}-\mathrm{r} 686$ ). If Juliana had knowledge of medicine, as mentioned by Desideri, this might have been because of the husband mentioned in this letter. Alternatively, her knowledge of medicine could have come from her father, were he in fact the surgeon in Ketelaar's account. It could also be likely that the two accounts have confused her father with her husband or vice versa.

The viceroy mentions that Juliana had fallen out of favor with the Mughal court and been imprisoned for two months; although Vasco Fernandes does not seem to know why Juliana fell out of favor, he writes that it was partially through the interventions of an ambassador sent by the Estado that favor was restored to her, after which she continued to be valuable to Aurangzeb and Bahadur Shah I. ${ }^{17}$ Here,

\footnotetext{
15 Ibid., p. 3 .

16 Ibid., p. I I9.

17 Ibid., p. 127.
} 
the Estado is portrayed as having worked diligently to protect Juliana's position in court, for she was representing their interests as one of their own. In these correspondences, Juliana is referred to as the procurator (procuradora) of the Estado. This title denoted her official role as lobbyist for the Portuguese state in the Mughal court, in exchange for land grants that made her a vassal of the king. D. Rodrigo da Costa, viceroy of Portuguese India who governed from I 707 to I 7 I 2 , writes that the state owes her much gratitude and many fineries, for she has entered the esteem of the Mughal king as a Portuguese woman and a good Christian, virtuous among Moors.

Juliana's success as a vassal and diplomat is indicated by a letter written by D. Rodrigo to João V, in which he writes: "It is not beneath your majesty's dignity to honor her letter with a response, given the good she does for the state.” D. Rodrigo also mentions a Padre João de Abreu at the Mughal court, through whom Bahadur Shah I communicates that he wants weapons such as those that the Portuguese have, and through whom Juliana sends her letter to the king. ${ }^{18}$ João $\mathrm{V}$ acknowledges receiving Juliana's letter, and asks the viceroy to communicate to her his thanks. ${ }^{19}$ The viceroy Vasco Fernandes César de Meneses, who replaced D. Rodrigo, continued to maintain strong ties with Juliana. She was rewarded with a village by the Portuguese and was seen as indispensable to their mission. ${ }^{20}$

Furthermore, because of her Portuguese origins, the claims of the Estado extend to Juliana's family. While her husband is not mentioned again, the correspondences record that Juliana had a married granddaughter, and a grandson called Joseph Borges da Costa, for whom she asked for provisions. She also asked for provisions for Diego Mendes, the brother-in-law of Joseph Borges da Costa. ${ }^{21}$ A letter from the viceroy to João Gomes Febos (the director of Portuguese missions in Surat) written in I $7 \mathrm{I} 5$ records that Habits of Christ were sent to both men. These habits signified the political and religious claims of the Estado on Juliana and her family. Recipients of the habit of the military Order of Christ were usually pure of blood, which meant in essence that they were not descended from Jews or Muslims, and the title allowed for the granting of pensions and social prestige. In some cases, habits were granted to people of mixed blood, and it is not clear whether the grant-

\footnotetext{
18 Ibid., pp. I I I-I I 3 .

19 Ibid., p. I 20.

20 Ibid., pp. I 22-I 23.

21 Ibid., pp. I 44-I 46.
} 
ing of these habits to Juliana's family members represented a rule or its exception. ${ }^{22}$

In the last of the letters published by Gracias, Vasco Fernandes assures Juliana that he will do anything she desires, and he writes to João $\mathrm{V}$ to say that he is careful to keep up a good correspondence with Juliana and to conduct affairs to her liking, hoping that in gratitude she will return the favor to the Portuguese nation. ${ }^{23}$ In I 7 I 5 , he records that Juliana must be at least seventy years old and worries that her grandson might fall from the esteem of the Mughal court and lose his lands; this is why she might be obliged to buy a village for him in Portuguese India. Concern about both Juliana's age and the possibility of losing her allegiance can be read into Vasco Fernandes's correspondences of this year. In another letter to Juliana, the viceroy writes that the Estado owes her much diligence and hopes that she will continue to favor the Portuguese. "We are unlike other Europeans," he writes, and emphasizes that the Portuguese want no glory for themselves; rather, they wish only to conserve the reputation of the king. "Write to me," he implores. "It has been a long time." 24

While Desideri sees Juliana as broadly Christian and European, this letter shows how the Estado, vying with other Europeans for the king's ear, was anxious to maintain ties with Juliana, in the hope that she would favor the Portuguese over other Europeans, especially given that she was Portuguese herself. Juliana's own allegiances, which Gracias depicts as patriotic toward her homeland, might have been different. A clue to the lag in correspondence alluded to by the viceroy might be found in the accounts of Desideri and Valentyn. Desideri writes that Juliana has long been asking the king's permission to retire to the convent of St. Monica at Goa; however, this has not been granted, given all the services she renders to the empire. ${ }^{25}$ Valentyn too writes that Juliana, following the death of Bahadur Shah, mentioned that she wished to go to Goa. ${ }^{26}$ The death of her patron Bahadur Shah I in I 7 I 2

22 Ibid., p. I45. For Habits of Christ in Portuguese enterprises, see Fernanda Olival, "Structural Changes within the I6th Century Portuguese Military Orders," E-Journal of Portuguese History 2, no. 2 (2004): I-20. There is evidence that on rare occasions, people of mixed blood were inducted into the order. See José da Silva Horta, "Evidence for a LusoAfrican Identity in 'Portuguese' Accounts on 'Guinea of Cape Verde' (Sixteenth-Seventeenth Centuries)," History in Africa 27 (2000): 99-130.

${ }_{23}$ Gracias, Uma Dona Portuguesa na Corte do Grao-Mogol, pp. I $58-162$.

24 Ibid., p. I40.

25 Desideri, Account of Tibet, p. 68.

${ }^{26}$ Hosten, "Family of Lady Juliana Dias da Costa," p. 48. 
and her own advanced age could have meant that Juliana wished to distance herself from political concerns and perhaps retreat into a life of seclusion.

Although her wishes are difficult to ascertain, it seems fairly certain that the Portuguese, with whom she had a prolonged correspondence, quite rightly perceived her as a skillful politician. She had managed to hold lands in both Mughal and Portuguese India and was trusted by both the Mughals and the Estado during a time when the power of each appeared to be faltering. Juliana herself seems to have assessed the viceroys with whom she was dealing correctly; were she to lose favor or be allowed to retire to Goa, they would in fact assist her family members who were either purely Portuguese by blood or worth an exemption to the rule that they be Portuguese by blood in order to claim such assistance.

\section{Between Pirates and Providence}

Despite the focus of the Portuguese government on purity of blood when inducting people into the Order of Christ, the entrenchment of the Portuguese in India and of intermarriages between Indians and Europeans provides a more layered context for Juliana's Christian/Portuguese/Mughal identity. The Mughal Empire and the Estado, in spite of their competition over sea trade, cannot be clearly demarcated from one another in a landscape where intermarriage was common, as were beliefs about royal blood from one house joining with that of another because of the vagaries of fate. Although the instability of sea trade affected economic enterprises, the displacement caused by pirates and plunder often brought fortune to individuals; women and men captured and sold as slaves could be integrated into royal families and, consequently, experience tremendous rises in power. In later centuries, lives such as Juliana's seem to have lent themselves to a particular kind of storytelling in which biographical facts are absent but the romance of foreign origins, captures at sea, and dramatic twists of fate lives on.

Gracias, for instance, includes in his historical sketches of the Mughal Empire an account of mixed marriages between Europeans and Indians. He sees Luso-Indian history as unexplored territory to which he wishes to make a modest contribution. ${ }^{27}$ Gracias points out that

27 Gracias, Uma Dona Portuguesa na Corte do Grao-Mogol, p. 3. 
during a time when shipwrecks were frequent as were raids on ships, Portuguese women would often end up in the courts of distant kings. ${ }^{28}$ The placing of official documents about Juliana Dias da Costa in the midst of these romantic speculations show another aspect of how Gracias frames Juliana's life; she is one of many European women who are a part of Indian society, and the vagueness of her origins is supported by the turbulent times in which she lived.

Gracias also discusses the speculation that the wife of the Mughal king Akbar (d. I605), Maryam Makani, could potentially have been a Portuguese woman called Maria Mascarenhas, whose sister, also named Juliana, was married to Jean-Phillipe de Bourbon de Navarre, a scion of the French royal house who had run away to Akbar's court in India. ${ }^{29}$ This is faulty; Maryam Makani (d. I604) was the title given to Akbar's mother, Hamida Banu Begum, who came from a Persian family and whose marriage to Akbar's father Humayun (d. I 556) is well documented in Mughal sources. The honorific title translates to "she who dwells with Mary," and royal women often held such titles, regardless of religion; one of Akbar's Hindu Rajput wives, Harka Bai (d. I622), for instance, held the title of Maryam Zamani (Mary of the Age). Nonetheless, Gracias's collection of stories, which contain both fact and embellishment and seek to find Christian influences on Akbar through European women, shows the appeal of such stories even after the end of the Mughal Empire.

In the late nineteenth and early twentieth centuries, the stories of the two Julianas would come to be mixed, perhaps because of the marriages of Juliana Dias da Costa's descendants into French families. Gracias's source for discussing Akbar's possibly Christian wife, Mary, who may or may not have been either Maria Mascarenhas or a woman called Maryam Makani, or another Mary altogether, is a work titled "Reminiscences of Agra" by the Franciscan missionary Frederic Fanthome, written in I 895. Writing about the Catholic Mission in Agra and about Akbar's support of Christians, Fanthome is convinced of the existence of a Christian wife called Mary, whose influence on Akbar has been denied by Muslim historians. Fanthome believes fully the story of Jean-Phillipe de Bourbon and discusses Akbar's leanings toward Christianity with the same conviction that Desideri puts forth

28 Ibid., p. 47 .

${ }^{29}$ For these intermarriages, see, for instance, Gracias, Uma Dona Portuguesa na Corte do Grao-Mogol, pp. I97-I99. For Gracias's discussion of Maria Mascarenhas and her sister Juliana, see pp. 48-49. 
Bahadur Shah I's inclination for the religion. Themes of Christianity and conquest then appear to be central to how Juliana's story is understood even by later writers with commitments to these themes. In the accounts of these writers, Juliana is a Christian woman who represents the symbolic marriage of Christianity to the Mughal royal house. ${ }^{30}$

The contemporary author Shahryar M. Khan, himself a descendant of the royal family of Bhopal, which claims marriage ties to the Bourbons of India, writes that even today family lore continues to hold that Jean-Phillippe ran away from France because of a duel and was sold by Turkish pirates to the Ottoman king Sulayman the Magnificent ( $\mathrm{r}$. I 520-I 566). Following several adventures, Jean-Phillipe eventually arrived at the court of Akbar in India. Then, two sisters called Maria and Juliana Mascarenhas also arrived with a similar tale of capture; they had been sent from Portugal to be betrothed to Portuguese military officers but were abducted by the Dutch on the way and sold as slaves in Surat. Akbar married Maria and Juliana married Jean-Phillipe. Whether or not this theatrical tale is true, points out Shahryar Khan, it is believed by many. ${ }^{31}$ Today, for the Bourbons of India, the romance of foreign origins enhances prestige in a postcolonial state; the Bourbons are different by virtue of having a bloodline that comes from Europe.

Interest in lost scions of European houses also continues to fascinate audiences abroad. An article in The Guardian on 3 March 2007 titled "Found in India: The Last King of France" reports that a Balthazar Napoleon de Bourbon, who has never set foot in France but chosen French names for all his children, has caught the eye of another Bourbon descendant, a Prince Michael of Greece, who lives in Paris and has written a historical novel titled "Le Rajah de Bourbon." Balthazar is reported as saying his family frequently draws interest from Europeans, is proud of his distinguished lineage, and expresses some discomfort with the skepticism of historians. ${ }^{32}$

In an earlier context, Christine Isom-Verhaaren has documented how fabricated accounts of royal French women in the Ottoman harem following dramatic captures at sea were used to support the political aspirations of states such as the Ottoman Empire and France beginning

${ }^{30}$ For the original source, see Frederic Fanthome, TOSF, Reminiscences of Agra (Calcutta: Thacker, Spink and Co., I 895), pp. 5-1 7 .

31 Shahryar M. Khan, The Begums of Bhopal: A Dynasty of Women Rulers in Raj India (London: I. B. Tauris, 2000), pp. 60-6r.

32 Angelique Chrisafis, "Found in India: The Last King of France," The Guardian, 3 March 2007, accessed I3 May 20II, http://www.guardian.co.uk/world/2007/mar/o3/india france. 
in the sixteenth century and continuing onward to the twenty-first. One of the more popular of these traditions was that of a French princess becoming the mother of a sultan, which made him a descendant of both houses. In the case of this particular princess, sources are quick to mention that she stayed true to her Christian faith. ${ }^{33}$ In these European/Ottoman narratives too, Christianity comes to be married to the royal house and to exercise an influence though the romanticized figures of women whose stories hold popular appeal even in modern-day Turkey.

A parallel story points to the cartographic world of the Jesuits and the celebrated women who were able to navigate it as saints. Gauvin Alexander Bailey documents the life of Catarina de San Juan ( I608I688), a woman who was allegedly born into an aristocratic family in Mughal India and came to New Spain in the early seventeenth century. She too became a favorite of the Jesuits, and hagiographies of her record that while her maternal grandfather was a Mughal prince, her parents had Christian leanings. She escaped marriage to a Muslim by hiding in a cave of vipers and fleeing around I6 5 to Portuguese territories. She narrated that she was then captured by pirates in Cochin, baptized as Catarina de San Juan by some Jesuits, taken to Manila, and eventually sold into New Spain; she arrived in Acapulco in I62 I. Despite her marriage to another Asian immigrant, Catarina's hagiographers report that she remained chaste and gained a reputation as a prophet who saw the world through imaginary air travel. According to Bailey, her Jesuit biographer Alonso Ramos notes down her trips to Asia in great detail and makes sure to point out that it was Jesuit enterprise that allowed for the Christian conversions she witnessed among the kings of Japan, India, and China. ${ }^{34}$

These parallel stories, in which French princesses command power in the Ottoman harem, or a Mughal/Christian princess blessed with extraordinary powers is able to aid Jesuit enterprises through prophetic visions, help contextualize the power that Juliana Dias da Costa held in Jesuit imagination. Unlike a man, Juliana posed no political threat to other men, and as a woman, she was able to inspire through virtue and

33 Christine Isom-Verhaaren, "Royal French Women in the Ottoman Sultans' Harem: The Political Uses of Fabricated Accounts from the Sixteenth to the Twenty-first Century," Journal of World History i 7 , no. 2 (2006): I 59-195.

34 Gauvin Alexander Bailey, "A Mughal Princess in Baroque New Spain: Catarina de San Juan ( I606-I688), the china poblana," Anales del Instituto de Investigaciones Estéticas 7 I (1997): 37-73. 
chastity. Displaced from her origins by shipwreck or plunder and taken into the Mughal household but holding steadfast to her faith, the Jesuit Juliana Dias da Costa embodies an intact internal code of values that does not change despite her circumstances. Through her adherence to this code, she exercises spiritual power and rises to become a politically valuable connection between Europeans and the Mughal court. For Gracias and Fanthome, facts about either Juliana Mascarenhas or Juliana Dias da Costa do not matter as much as the possibilities both women present for visualizing the Mughals as partial to Europeans by virtue of shared bloodlines, or partial to Christianity as a result of witnessing the extraordinary faith of women like these.

Hagiographical Revisions: Bruit's Bibi Juliana, Gentil's Joan of Arc

Hagiographical understandings that were linked to Jesuit imagination and European enterprises form a framework through which the accounts of Gaston Bruit and Jean-Phillipe Gentil can be read; both Frenchmen write about Juliana with special attention to the quality of her faith and to her extraordinary closeness to Bahadur Shah I. ${ }^{35}$ Tales of pirates and providence form the backdrop to these hagiographical framings, and both authors' accounts of Juliana seem to draw upon earlier sources such as Desideri and Valentyn. Gaston Bruit's account, Ahvāl-i Bibi Juliana (The Circumstances of Lady Juliana), tracks the changing fortunes of a woman who came as a stranger to the Mughal court. Bruit's "Bibi Juliana" is woman of rare piety and distinction, and he hopes that whatever he has heard from his elders will be contained in writing for the purposes of history ${ }^{36}$ Bruit's account contains within it details of Juliana's everyday life that are lacking in other accounts, and his account differs from others because it frames Juliana as having shown loyalty to the king during times of adversity and as having had the forbearance and patience of a saint during hard times of her own, for which she was rewarded by God and king.

Bruit begins his story of Juliana with the Mughal king Jahangir (d. I627), who faced rebellion from his son Khurram, who would later

${ }^{35}$ For an analysis of the varied landscape of the seventeenth century, see Sanjay Subrahmanyam, "Further Thoughts on an Enigma: The Tortuous Life of Nicolò Manucci, I638 c. I 720," Indian Economic Social History Review 45, no. I (2008): 35-76.

36 Bruit, Ahvāl-i Bibi Juliana, fols. I-2. 
crown himself with the title Shah Jahan (d. I666). In Bruit's account, or the accounts of his elders, Jahangir died from sorrow at this rebellion, and his sister, from grief at the loss of her brother, went for haj. On the way across the sea, she met with Portuguese ships. Her belongings were seized as were goods for trade, and she was brought, along with her travel companions, as a prisoner to Goa. When Shah Jahan secured her release, she returned with a harsh recrimination to her nephew: "What would become of your kingdom and your power if at the beginning of your reign, the Portuguese are so heedless and headstrong, that they feel no need to consult anyone about their doings, and feel free to disrespect your women and take them prisoners? How will the order of your empire and the safekeeping of your kingdom end if this is its beginning?" 37 The incensed and shamed emperor, according to Bruit, grew determined to attack the Portuguese stronghold of Goa and to punish the foreigners. Bruit writes that Shah Jahan's blockade of Goa, which included his attack on nearby Hugli, led to his victorious armies returning with prisoners. These prisoners included Bibi Juliana, a girl at the time, and her mother.

The official chronicle of Shah Jahan's reign mentions Shah Jahan's successful attack on the port city of Hugli in $1632 .{ }^{38}$ The chronicle narrates that a number of farangis, a term that translates literally to "Franks," but refers to Europeans in general, who had initially come to trade, had set up fortifications at Hugli. They had then proceeded to take control of villages around Hugli, converted locals to Christianity, and then shipped them off to settlements abroad. The chronicle makes no mention of the seizing of ships, and particularly of a ship belonging to Shah Jahan's aunt. ${ }^{39}$ The expression of female outrage that Bruit mentions could be a reference to an earlier incident. In I6 I3, a ship belonging to Akbar's wife Maryam Zamani that was carrying pilgrims to Mecca was captured by Portuguese pirates. This led to a reprisal from Jahangir and a Mughal takeover of the Portuguese town of Daman. ${ }^{40}$

Although Bruit's narrative of this attack merges elements of two

37 Ibid., fols. 2-3.

38 See Sanjay Subrahmanyam, "Staying On: The Portuguese of Southern Coromandel in the Late Seventeenth Century," Indian Economic and Social History Review 22, no. 4 (1985): 445-463.

39 Inayat Khan, The Shah Jahan Nama of Inayat Khan: An Abridged History of the Mughal Emperor Shah Jahan, Compiled by his Royal Librarian, ed. W. E. Begley and Z. A. Desai (Delhi: Oxford University Press, I990), pp. 84-87.

${ }^{40}$ See Ellison B. Findly, "The Capture of Maryam-uz-Zamānī's Ship: Mughal Women and European Traders," Journal of the American Oriental Society 108, no. 2 (I988): 227-238. 
historical incidents, the displacements caused by these attacks on European settlements figure in Portuguese accounts and in the accounts of Catarina de San Juan's hagiographers of her miraculous escape from India. The particular vulnerability of women in such attacks features in Bruit's tale when he recounts both a Mughal woman's outrage and the arrival of Juliana at court as an indirect result of this outrage. Following the attack, Bruit writes that both Juliana and her mother were given to "a begum of the household," whom they served until her death. Following the death of the begum, Juliana and her mother came into the care of a Padre Anton Magellan. After her mother died, the padre arranged for Juliana to be married to "a man of her own people," presumably the same Portuguese man mentioned in Gracias's correspondences. The man is not named and, according to Bruit, died in battle.

Bruit writes that on the ascension of Shah Jahan's son Aurangzeb, Juliana decided to emerge from a long period of seclusion to serve at the household of the king, where she became the servant of Aurangzeb's wife, the mother of the prince Mohammad Moazam Bahadur Shah. Her service made her dear to the begum and consequently to the king. However, when the prince rebelled against his father, he was placed under house arrest with his mother and their servants relieved of their duties; this could be the period of disfavor mentioned by Valentyn and in the correspondences collected by Gracias. ${ }^{41}$ Bruit writes that Juliana, distressed at the separation from the begum, sought the oblation and prayers of Padre Anton. His prayers bore fruit, for after three months the begum wrote to Aurangzeb and implored that she be sent a servant. Persuaded by a surge of forgiveness, the king asked that a search for an appropriate servant be initiated. ${ }^{42}$

When the news reached Bibi Juliana, she offered her services and settled on a price for purchase. She was then allowed to enter the household for three days, after which the begum was to decide whether or not to keep her. On both entry and exit, her belongings would be searched. Juliana set off with a ceramic jar for holding water, which was emptied by guards at the palace. When the begum recognized Juliana, she was overcome with happiness. Bruit writes that the begum took Juliana into her confidence and, out of fear of the king, sent her away on the pretext that she did not want her services. With Juliana she sent precious jewels that she hid in Juliana's water flask, and Juliana

${ }^{41}$ Bruit, Ahvāl-i Bibi Juliana, fols. 4-5.

${ }^{42}$ Ibid., fols. 6-7. 
was able to conceal these from the guards outside. The search for a servant continued for nearly two weeks, and when none was found, the begum said she would settle for the woman she had sent away, and Juliana returned to the household of the begum. ${ }^{43}$

Bruit's account emphasizes Juliana's honesty and discretion; she is not tempted by the jewels and is able somehow to conceal them. Perhaps because she is not tempted by wealth and power, both come to her; Bruit writes that the prince promised Bibi Juliana that were he to become king after Aurangzeb's death, he would grant her all she wanted and give her a rank higher than all of the nobility. This came to pass, and Bruit records Bahadur Shah I's victory over his brother, praises for his reign ( I 707-I 7II), and his fulfillment of his promise to Bibi Juliana. She was to become one of those closest to the king, writes our author, and to be higher in rank than all his nobles. Her level was such that when she would ride, she would be accompanied by five or six thousand men on foot. Other people, no matter what their level, would seek her counsel and favor, and if she interceded on their behalf, their wishes would be granted. "But this kind bibi," writes Bruit, "in whose soul chastity and modesty [iffat] were embedded, despite this wealth, honor, and high position, would spend all her time in humility and piety [taqwa]."

Bruit narrates that the incorruptible Juliana would begin the day in the early hours of the morning, in which she would purify herself and retreat to a room where she would worship her true creator alone. She would emerge four hours later from her place of worship [ibādat khäneh] to join the women of the household. Another four hours would pass in the preparation of food, including the king's favorite dish, rice with lentils, which he would devour with delight. ${ }^{44}$ Another four hours would be devoted to sewing, after which she would put on her formal clothes [libas-i darbarī] and attend to the tasks of the court. ${ }^{45}$ In Bruit's account, Juliana moves from the sacred realm of solitude and prayer into the space of the household occupied by women, and eventually dons formal clothes to join the king in the tasks of administrating an empire. Like Desideri, Bruit sees Juliana as humble and pious despite having immense political power.

Her loyalty to the Mughal household, writes Bruit, continued after the passing of Bahadur Shah I in I 7 I2; she served his son and succes-

\footnotetext{
${ }^{43}$ Ibid., fols. 7-9.

44 Ibid., fol. I3.

45 Ibid., fol. I4.
} 
sor Jahandar Shah (d. I 713), and his nephew and successor Farrukhsiyar (r. I 7 I3-I 7 I9). ${ }^{46}$ Farrukhsiyar was strangled to death on the order of the Sayyid brothers (Hasan Ali Khan Barha and Husayn Ali Khan Barha), the two powerful army generals responsible for placing a series of puppet rulers on the throne following the death of Aurangzeb, and Bruit writes that the brothers began to spread chaos [fitna] in the land and crowned several kings one after the other. Finally, the grandson of Bahadur Shah I, Muhammad Shah (r. I 719-I 748), came to the throne with the help of the brothers and, according to Bruit, brought happiness to all of India.47

When discussing Bibi Juliana's role in sustaining the kingship of Muhammad Shah, Bruit focuses on the power of her prayers. He writes that the mother of Mohammad Shah grew terrified of what the brothers were capable of doing to her son and asked Bibi Juliana to pray to her saints to keep the king safe from the destructive whims of the two brothers. Bibi Juliana changed the name of the prince to Muhammad Yahya and placed him under the guardianship of John the Baptist (referred to as Sahib-i Yohāna), with the extraction of a promise that were he granted the strength and independence needed for governance, he would distribute charity in the name of the saint.$^{48}$ This too, like all of Juliana's prayers, came to pass. In Bruit's story, two promises mirror one another: Juliana is promised wealth by a king in exchange for her loyalty to him, and a king is promised victory in exchange for his loyalty to Juliana's saint.

Bruit's story also contains elements of Desideri's, in which the conception of Muhammad Shah's grandfather, Bahadur Shah I, took place because of Juliana's prayers, after which he was named Yahya. Bruit is writing nearly four decades after Desideri, who was in India during Juliana's lifetime. Legendary tales attached to Juliana's piety and power after her death consisted of some overlapping elements, which included her devotion to John the Baptist and the ability of such devotion to influence the fortunes of the kings she served. In these tales, specific details about the kings who were blessed by her and the capacity in which her prayers protected them seem less relevant, just as biographical details about her parentage matter less than details that illustrate a broader moral aspect of her character, such as her indifference to wealth. Just as Bruit conflates two instances of Mughal attacks on

\footnotetext{
46 Ibid., fol. I 5.

47 Ibid., fol. I6.

48 Ibid., fol. I 7 .
} 
Portuguese settlements to create a general narrative about plunder and displacement, he uses an earlier tale that might have been modified with time to point to Juliana's influence and that of John the Baptist on successive kings. When the Sayyid brothers meet their downfall, Bruit writes that Muhammad Shah paid what he vowed to the saint, and raised the position of Bibi Juliana, who died during his reign. ${ }^{49}$

Next to nothing is known about Bruit himself, or about the stories he collected to compose a narrative of Juliana. Other than its beginning, which does not contain praises to God, the prophet, and his descendants, Bruit's account follows the Persianate convention of praising the wisdom and personal character of the patron, Major Gentil (d. I 799), for whom it is composed..$^{50}$ The storytelling aspect of Bruit's account lacks details about Juliana's service to the Portuguese and Dutch; only her service to the king in adversity and prosperity seems to matter. The threads of causality according to which a raid on a Portuguese settlement leads to the placement of a European, Christian woman close to a Mughal king suggest that Bruit might have written his account to be circulated among European and Indian audiences familiar with Persian, and perhaps with stories of Juliana herself.

Bruit's choice of language and following of Persianate convention points to the mixed sensibilities of his possible European audience. His patron Jean-Baptiste Gentil was one of a number of Frenchmen present in Mughal courts and in the courts of successor states in the eighteenth century. Major Gentil had been in service to Shuja' ud-Daulah (d. I 775), the Nawab of the princely state of Awadh, and held a high rank in his army. He had also served as captain of the French service at the Mughal court. ${ }^{51}$ Gentil's own account of his years in India, the Memoires sur l'Hindoustan, ou Empire Mogul, was published in Paris in 1822 , after being edited by his son. Besides having in his possession Gaston Bruit's Persian account of Juliana, Gentil married Juliana's grandniece Teresa Velho in I 772, a fact that he mentions in his memoirs. If Gentil had asked Bruit to compose a text in Persian that consisted of collected stories about Juliana, part of his family by marriage, such a history would have carried with it the romance of India in France, in

49 Ibid., fols. I8-I9.

50 Ibid., fols. I-2.

${ }^{51}$ I draw my information about Major Gentil from Sanjay Subrahmanyam, "The Career of Colonel Polier and Late Eighteenth-Century Orientalism," Journal of the Royal Asiatic Society Io, no. I (2000): 43-60. For Gentil's atlas, see Susan Gole, Maps of Mughal India: Drawn by the Colonel Jean-Baptiste-Joseph Gentil, Agent for the French Government to the Court of Shuja-ud-Daula at Faizabad, I770 (New Delhi: Manohar, I988). 
much the same way the romance of French origins is attached to the Bourbons in India today.

Gentil's own memoirs contain a short biography of Juliana, which must have been drawn partly from Bruit's account and partly from stories about Juliana told to him by his wife, Teresa. While the accounts discussed above mention nothing of Juliana's sons or daughters, according to Filippo de Filippi in his notes to Desideri's travels, Juliana had introduced to court a sister called Angelica. Angelica married Velho de Castro, and her daughter Isabella Velho took over from Juliana her court duties. Isabella, according to Filippi, later married Diego Mendes de Castro, by whom she had five daughters. The youngest of them was Gentil's wife, Teresa Velho. ${ }^{52}$ Filippo de Filippi's Diego Mendes, Gentil's father-in-law, is the same who received provisions from the Estado at Juliana's request. Diego Mendes then might have provided Gentil with the information about Juliana that forms his sketch of her in his memoirs, as could his wife, Isabella.

Gentil was familiar with Valentyn's account, because his chapter on Juliana names her as the daughter of an Augustino Dias d'Acosta and says she was born in Bengal in I658. ${ }^{53}$ Gentil also mentions Juliana's influence in the Mughal household, especially over Bahadur Shah I.54 Like Valentyn, Gentil recounts Juliana's prophetic vision: she told the king that victory was assured to him and said that he was to offer his support to the Christians after this came to pass..$^{55}$ Gentil's sketch of Juliana, who rode besides the king on an elephant, evokes Joan of Arc, who is a champion for her Christian faith, quite literally, on the battlefield. Bearing the standards of the cross, Gentil's Juliana is heroic, powerful, and masculinized. Following an account of the spectacle of war between the two brothers, Gentil writes that the victorious prince said of Juliana: "Si Juliana était homme, j'en ferais un vézyr" (If Juliana were a man, I would make her a minister). After the battle, Juliana was declared the protector of the Christians and was given wealth, a royal title, and the palace of Dara Shikoh. ${ }^{56}$ According to Gentil, the coronation of the king was held on the same day as the feast of John the Baptist, and it was Juliana who crowned the king.

52 Ippolito Desideri, An Account of Tibet: The Travels of Ippolito Desideri of Pistoia, S.J. I 7 I 2-I 727, ed. Filippo de Filippi (1932; repr. RoutledgeCurzon, 2005), pp. 375-376.

53 Gentil, Memoires sur l'Hindoustan, p. 367.

54 Ibid., p. 369 .

${ }^{55}$ Ibid., pp. 369-370.

${ }^{56}$ Ibid., pp. 373-374. 
Both Juliana and Jean-Baptiste Gentil inhabited several cultural worlds. Gentil's personal history is tied to both India and France, just as Juliana's is to Portugal and India. Their association with Indian ruling families, their familiarity with Indian languages, and their placement within a circle of Europeans who spent considerable time in India makes them products of a cultural fluidity that disappeared after formalized colonial rule, in which Indian and European spaces became clearly demarcated. The retreating landscape of the past inhabited by Juliana is one that men such as Gracias hoped to capture by gathering the fragments. In the same way, in writing his memoirs nostalgically in France, Gentil composed sketches of many of the characters he encountered or heard of in India, and his sketch of Juliana as one of these ended with his own ties, by marriage, to her family. Juliana's descendants, as an embodied link to this retreating landscape, continued to hold the interest of scholars of the nineteenth and twentieth centuries. ${ }^{57}$

\section{Myth, Memory, and the Descendants of Bibi Juliana}

Among Europeans in British India, stories of Juliana and the favor accorded to her by Bahadur Shah I would have made for popular circulation among Europeans married into her family in later generations or Europeans seeking similar advancement in India. In an article for the Journal of the Punjab Historical Society titled "The Family of Lady Juliana Dias da Costa (I658-1 732)," the Rev. H. Hosten, SJ, speculates that perhaps Gastin Brouet is Augustin Bravette, a man who married into Juliana's family; gravestones at Agra, investigated by Hosten, suggest as much. This could mean that Bruit's account of Juliana's years with Father Anton come from family lore as well, given that Bruit refers to tales that are found in no other source about Juliana. Hosten also addresses the confusion between Juliana Dias da Costa and Juliana Mascarenhas, whom he says was an Armenian woman doctor at Akbar's court..$^{58}$

Hosten's need to address this confusion when writing in I9r 8 points to how, in these years, the stories of the Bourbons and those of Juliana Dias da Costa had been tangled up with one another to the extent that they warranted scholarly investigation. At the heart of the

57 See for instance, C. Wessels, SJ, Early Jesuit Travellers in Central Asia, I603-172 I (The Hague: Martinus Nijhoff, I924).

${ }^{58}$ Hosten, "Family of Lady Juliana Dias da Costa," pp. 40-4I. 
tangle were Juliana's descendants, who appear in several places in the correspondences and historical inquiries of the early twentieth century. The Journal of the Royal Asiatic Society in 1902 carried a short article by the historian William Irvine titled "Note on Bibi Juliana and the Christians at Agrah." The article consists of three letters written by J. P. Val D'Eremao, which were in the possession of the British scholar Henry Beveridge. In these letters, written a year before his death, Val D'Eremao (d. 1896) writes that Bibi Juliana was his paternal grandmother "one degree back" and that his family still has possession of a jāgir from Bahadur Shah I. While he does not know anything of Gentil, Val D'Eremao writes that he recalls, from childhood, the names Bourbon and "Brouet."

Val D'Eremao also writes that his grandfather, Captain Emmanuel, was Bibi Juliana's son. In his note preceding the letters, Irvine writes that Val D'Eremao's statement is to be treated as "legendary," because Bibi Juliana died in the year I 734 at the age of seventy-five. She could hardly have been a mother past I 704 and Captain Manuel, as he was known, must have been "in the period of active manhood" in 1803 . This would mean that Manuel, or any child of Juliana's for that matter, would have been ninety-nine years old in 1803 , which was improbable. Irvine concludes that therefore Captain Manuel was not her son. Perhaps, speculates Irvine, he was the lady's grandson. ${ }^{59}$ Irvine derives his information about Juliana partly from a Mughal source, the Tarikh-i Muhammadi, which records that Juliana, a farangi woman who was a favorite of the late Bahadur Shah, died in Delhi in I734. He is also aware of the memoirs of Gentil. ${ }^{60}$

Even though Irvine expresses surprise at the relative silence of Mughal sources about Juliana's life, this silence would indicate that the prominence enjoyed by her was less unusual to Mughal eyes than it might have been to the Jesuits or to Europeans associated with English, Dutch, French, and Portuguese enterprises. Given that Juliana seems to have been absorbed into the Mughal household, her family of origin would no longer factor into how she was perceived in Mughal sources. Also, since several Mughal women, such as Maryam Zamani, held lands; took part in political negotiations, charitable patronage, and

${ }^{59}$ For this correspondence, see William Irvine and J. P. Val D’Eremao, "A Note on Bibi Juliana and the Christians at Agrah," Journal of the Royal Asiatic Society of Great Britain and Ireland ( 1903 ): $355-358$.

60 William Irvine, The Army of the Indian Moghuls: Its Organization and Administration (London: Luzac Sc. Co., I903), p. I53. 
trade; and encamped with kings during times of war, Juliana's power would not seem different from that of any other prominent Mughal woman. ${ }^{61}$

What Mughal documents do reveal is that the villages held in Juliana's name seemed to have passed to the D'Eremao family, who claimed to be direct descendants of hers, and to be linked with the Bourbons as well. The claims of the family are recorded in the writings of Sir Edward Maclagan who reports, in 1932, that the D'Eremao family "is now in poor circumstances." 62 The distance between these poor circumstances and tales of lost grandeur, evidenced by deeds to lands, would suggest that nostalgia fueled some of the more elaborate claims of the D'Eremao family. At the time of Maclagan's writing, the D'Eremao family claimed that the title of D'Eremao came from the title of Durr-i Yaman or Durr-i Oman (pearl of the Yemen or Oman) conferred by the Emperor Bahadur Shah on their ancestress, Juliana. ${ }^{63}$

There is no evidence that Juliana was given such a title, nor is there evidence that she had any ties to the Bourbons. The Bourbon story proposed by the D'Eremao family and reported by Maclagan was that a Jean-Baptiste Gaston de Bourbon, duke of Orleans and the second son of Henry IV, escaped to India and occupied a place at the Mughal court a century after Akbar's death in 1605 . In this story, Juliana was married to Gaston de Bourbon. But Jean-Baptise Gaston de Bourbon died in Blois in r66o, Maclagan writes, and adds that "the whole story is a confused one." ${ }^{64}$ Another confused element is added to the story by Captain Manuel's grandson Paul D'Eremao, who made a statement in 1885 according to which Juliana was a physician who cured Bahadur Shah's mother of a disease in the breast and whose sister Isabel married a D'Eremao. While Paul D'Eremao's statement concurs with other sources that mention Juliana's medical knowledge, the story of her curing Bahadur Shah I of a disease seems to be a later addition. Isabel remains undocumented save for this statement, and the link between the earlier Juliana and Jean-Phillipe de Bourbon is dismissed

${ }^{61}$ See Ruby Lal, Domesticity and Power in the Early Mughal World (New York: Cambridge University Press, 2005); Ellison Banks Findly, Nur Jahan, Empress of Mughal India (Oxford: Oxford University Press, I 993); S. A. I. Tirmizi, Edicts from the Mughal Harem (Delhi: Idarah-i Adabiyat-i Delli, I979); and Gregory C. Kozlowski, "Private Lives and Public Piety: Women and the Practice of Islam in Mughal India," in Women in the Medieval Islamic World, ed. Gavin R. G. Hambly (New York: St. Martin's Press, I998), pp. 469-488.

${ }^{62}$ Maclagan, Jesuits and the Great Mogul, pp. 186-187.

63 Ibid., p. I66.

${ }^{64}$ Ibid., pp. I66-I67. 
by Maclagan, given that no Jesuit source mentions him, even though Jesuit sources are full of stories of adventurers who find themselves in India and then rise to prominence. ${ }^{65}$

The most conclusive link between the D'Eremaos and Juliana comes from land grants such as those held by Manuel D'Eremao and passed, like stories, on to future generations. Both Captain Manuel D'Eremao and his son Lieutenant Domingo D'Eremao are buried in the D'Eremao cemetery, part of the lands once held by Juliana, and an officer for the Indian army, Brigadier Humphry Bullock (ı 899-I959), in an article for the Journal of the Punjab Historical Society, writes that "Captain Manuel appears to have succeeded to a jāgir of twelve villages near Delhi, part of the estates which had been granted by the Emperors to Donna Juliana Dias da Costa in recognition of her professional services." He adds that in his will, Captain Manuel had mentioned these lands and his claim to them through his paternal grandmother, Juliana. Captain Manuel's will then supports Irvine's statement that he was Juliana's grandson, and not her son. Bullock adds that Captain Manuel was known to all as "Manuel Sahib," and that he was visited frequently by the emperor Shah Alam (Bahadur Shah I), who once cooked a meal for him with his own hands. ${ }^{66}$

Nevertheless, if Captain Manuel's father was Juliana's son, the names of this son and his siblings remain unknown, as does the name of his wife. Perhaps Juliana had children with the Portuguese husband referred to in some of the sources discussed in this article. However, the D'Eremaos and their claims to Juliana raise a series of questions that are worth considering. For one, even though J. P. Val D'Eremao was, as Irvine said, of advanced age, it seems curious that he would have been in error about his own grandfather and assumed that Manuel was Juliana's son rather than her grandson. Second, what are the origins of the name D'Eremao? In an article for the Journal of the Punjab Historical Society, Rev. Father Felix notes that Juliana's seal, as reported by Gracias, had the engraving Fidavi Bahadur Shah Juliana (Juliana, loyal servant of Bahadur Shah), a fact that is corroborated by Gentil. ${ }^{67}$ There is no mention in earlier sources of the title "Durr-i Yaman" or "Durr-i

${ }^{65}$ Ibid., p. I65.

${ }^{66}$ H. Bullock, "Captain Manuel D'Eremao," Journal of the Punjab Historical Society I (I932): I55-I 7I.

${ }^{67}$ Rev. Father Felix, OC. "Mughal Farmāns, Parwānahs and Sanads issued in favour of the Jesuit Missionaries," Journal of the Punjab Historical Society 5 (I9r8): I-53. While published in $19 \mathrm{I} 8$, this was a paper read, presumably for the Punjab Historical Society, on I 8 January I9I3. 
Oman," claimed by the D'Eremaos to be the origin of their family name as given to Juliana by Bahadur Shah I.

Could it be possible that Juliana either married or had children with someone other than her unnamed Portuguese husband? If she did have a son outside of wedlock, there would have been no stigma attached to this in the Mughal household, nor would her children have been barred from inheritance and royal favor. ${ }^{68}$ If Juliana was a slave to the Mughal court — and Bruit's account suggests that she was, given that a price was set for her purchase-then it is not inconceivable that she might have had children out of wedlock. Did the sanctity attached to her spiritual persona by Europeans in the later years of her life lead to an omission of the parentage of these children? Could these children potentially have been of mixed blood? The persistent claims of her descendants, which surface two hundred years after her death, and the absence of the crucial link that ties her to these descendants- her own children and their names-is mysterious. What would justify the omission of an entire generation of Juliana's family from all records, to the point that it is her grandchildren and not her children, for whom she asked for provisions from the Portuguese?

A more prosaic explanation could be that at the time of her asking, her son(s) might have been deceased, but that would still not explain why nothing is known about these children or their father, through either oral accounts or written records. Another explanation might be that records pertaining to her children and husband have been lost; Maclagan mentions that Dara Shikoh's house, which she occupied, was damaged during Nadir Shah's massacre of I 739. At the same time, several records pertaining to her family and their claims to land seem to have survived despite the damage, along with possible evidence that she had children. Maclagan writes that deeds for her lands near Delhi show these lands to be granted to "Juliana and her sons." Maclagan also writes that "some fifty years ago," (in the r 88 os) these lands near Delhi were bequeathed to the Franciscan Mission at Agra by an old couple who claimed to be descendants of Juliana. ${ }^{69}$

By the time J. P. Val D'Eremao's letters surfaced, these lands must have been out of his hands, and the family was, as Maclagan reported,

${ }^{68}$ Concubinage in the Islamicate world has been discussed at length by Leslie Peirce in the context of the Ottomans, and her analysis applies to the Mughals and Safavids as well. See Leslie Peirce, The Imperial Harem: Women and Sovereignty in the Ottoman Empire (New York: Oxford University Press, I993).

${ }^{69}$ Maclagan, Jesuits and the Great Mogul, p. I86. 
in poor circumstances. While the absence of written records naming Juliana's children can be explained away, it is still difficult to explain the absence of any oral accounts about the generation through whom these claims to land lead back to Juliana. The most prosaic explanation of all could be that Juliana's line was descended through her sister Angelique; her sister's grandchildren would also be her grandchildren, and her lands would be passed down to any of Juliana's kin; the Mughals gifted land to families without being concerned with direct descendants. But the jumble of stories in later centuries, which includes the Bourbon myth and the conflicting claims of Juliana's descendants, makes the truth difficult to ascertain.

Interest in Juliana continues in the twentieth century and acquires the unmistakable texture of nostalgia. Rev. Father Felix conducted research in 1913 at the cemetery at Agra, which held the bodies of Europeans, and most notably, Jesuits, from a rapidly fading past. He writes that the Christian cemetery at Agra is the earliest Christian graveyard in North India. "We find there Europeans of all nations, English, French, Portuguese, Italian, German, Flemish, and even Swiss. Who were these people? How did they come here? What did they do?" Rev. Felix points to specific graves; these include "a fair soldier from the green island near a dark native Christian," forgotten artisans and merchants, and "the history of John Philip Bourbon de Navarre ... the Jesuit missions ... and the story of Dona Juliana Dias da Costa."70 Rev. Felix is aware not just of a lost past but of lost stories, including that of Juliana.

Rev. Felix believes that while the Jesuits have been maligned for having too many political ambitions, it is important to keep in mind all that they were able to accomplish in a foreign land where they worked zealously for the promotion of their faith. In telling the story of Juliana, Rev. Felix mentions how instrumental she was to Jesuit accomplishments. He cites the letter of one Father Figuieredo as saying that because of Juliana, Aurangzeb exempted "the Christians" from taxes to which "the Muhammadans themselves were subject." Rev. Felix also produces a grant from I695, which states that five padres and their descendants are exempted from paying the jizya tax, and one from Bahadur Shah, in the first year of his reign, which states that the jizya is not lawful upon mendicants. These exemptions continue through to the reign of Farrukhsiyar. ${ }^{71}$

\footnotetext{
${ }^{70}$ Felix, "Mughal Farmāns, Parwānahs and Sanads," pp. I I-I 2.

${ }^{71}$ Ibid., pp. 3I-36.
} 
Rev. Felix's account, when placed beside earlier accounts of Juliana's aid to Christians, is helpful in determining the limits of Juliana's benevolence. She seems to have made sure that Christian mendicants were exempt from taxes; however, this does not mean that her benevolence extended to all Christians of the empire, or that Christians could be seen as one entity. She was most certainly a favorite of Bahadur Shah I, and the Mughals' long history with Christian visitors to their courts and non-Muslim inhabitants in their households would mean that her influence could well have included prayers on behalf of kings and their children or the pledging of kings to John the Baptist. It is difficult to dispute that she held power and wealth; the Mughal land grants in her name testify to this, as do the documents collected by Gracias, which show that she was given considerable importance in her role as intermediary between the Mughals and the Estado by both parties. She seems also to have looked after her own interests by appealing to the Estado for provisions for two of her relatives and possibly by attempting to retire to a convent.

The power and prestige that Juliana Dias da Costa obviously held while she was alive stands in dramatic contrast to the poverty of her descendants in British India, where Rev. Felix finds himself surrounded by graves while hunting for lost stories. The elaborate claims of the D'Eremaos, however, are still formulated with the memory of Juliana's power close enough to be tangible, as evidenced by deeds to land held in the family, but distant enough to be understood through myths that weave in and out of the past without attention to historical detail, including details about how exactly the D'Eremaos come to be tied to Juliana. Jesuit attachment in the eighteenth century to their vision of Juliana as benefactress also stems from the loss of Jesuit power in India; it is as though the loss of political prestige on the part of both Juliana's family and the Jesuits leads to her becoming a mythic figure for both.

At the end of his paper, Rev. Felix laments that "after two hundred years of vigorous and fruitful life" the Jesuit mission was put to an end by a Christian king, Joseph of Portugal, in I $759 .{ }^{72}$ The irony of this is not lost on the reader: earlier writings portray the mission as a beacon of hope in a dark landscape and Juliana as admirable for her service to the Jesuits. The end of the Jesuit mission at the hands of a Christian

72 Ibid., p. 53 . 
king rather than a Muslim one resonates strongly with Rev. Felix. The graveyard with which he begins his piece then becomes a metaphor for the death of the mission and the India in which the mission was once able to flourish. And the names of Christians in this graveyard summon up the memory of Juliana, who was like the Jesuits in her zealous commitment to the propagation of her faith and the protection of its adherents.

\section{Shipwrecked in the Present}

My research for this article led me to the Gora Qabaristan in Karachi, a cemetery that evokes similar sentiments to those expressed by Rev. Felix in his attempt to document a past that remains buried beyond reach. Gora Qabaristan literally means "the burial place for white people," and is the colloquial name for a graveyard in which Europeans associated with the East India Company were buried. Today, it is a cemetery for the Christian community of Karachi. The oldest graves date back to the eighteenth century and include the graves of a Chaldean merchant, Muslims married into Christian families, and European merchants, statesmen, and traders. The graves in the Gora Qabaristan constitute a heritage that is shared between India, Pakistan, and Britain, and the shrinking space of that heritage in the homogenizing rhetoric of nationalism. In Pakistan and India, where Islam and Hinduism constitute dominant discourses that often render Christians invisible, the premodern world presents a past that both countries reject. Appropriately, garbage and sewage surrounds the graves in the Gora Qabaristan and the statues of angels that guard some of them.

I had managed to track down a Catherine Val D'Eremao in Karachi, and thought I might be able to find graves for her family, but I was unable to find any. Catherine is now in her nineties and lives in a Christian retirement home in an old part of Karachi. The home is a small place of leafy trees and high ceilings and antique tiles from the colonial period that is now surrounded by graceless apartment buildings, much like those that surround the cemetery. These high-rises are jarring encroachments of the present; obscenely tall and ominous, they suggest that it will only be a matter of time before they will prevail upon one of the last remaining buildings from another era. The cemetery and the old people's home are both haunting because they represent how the space for Christians in Pakistan is now vanishing; Christian spaces 
are often surrounded by security guards, and this attempt to protect them marks them even more acutely. They are no longer simply part of the landscape.

Catherine Val D'Eremao's memory has disappeared, and I was unable to ascertain much about her family from what she told me. However, she said that her father was French, and that her people came from very far away, but "became Indian" eventually. Despite having Alzheimer's, Catherine was aware that her family was different and that there was something about them that set them apart from others. She did not seem to know whether she was in India or Pakistan and mentioned that her family had something to do with the Isabella Thoburne College, established under British colonial rule in Lucknow by an American missionary. At the time I spoke to Catherine, I was in touch with Beverly Hallam, who provided me with a matriculation certificate for Catherine from Isabella Thoburne and evidence that Catherine was in fact the adopted daughter of one of the descendants of Juliana, a Valentine D'Eremao. Beverly herself descends through Captain Manuel D'Eremao through his son Domingo, whose daughter Hannah was the grandmother of Beverly's grandmother Vera.

Juliana has not been the subject of scholarly inquiry for nearly a century. The loss or relinquishing of lands by the D'Eremao family and the end of British rule in India in 1947 directly correspond with this disappearance. If the political visions of Jesuits and Europeans in India coupled with the claims of Juliana's descendants led to an interest in her in the past, today she has resurfaced for similar reasons. Beverly Hallam's work is part of a growing interest in familial and ancestral histories, and Bilkees Latif's semi-fictional account of Juliana stems in part from a reaction to polarized religious and ethnic identities in India today. The title of Bilkees Latif's book Forgotten points to her belief that there are lives from the past that challenge existing beliefs about identity. The graves in the Gora Qabaristan are evidence of this forgetting, as is the home where Catherine lives, where an inmate told me: "No one comes here. You come here in order to be forgotten."

This means that much like the shipwrecks and displacements that frame earlier narratives about her, Juliana remains shipwrecked in the fragmented relationship of nation-states with their past and in historiographical categories. Does she, for instance, belong to the history of Mughal India or to the history of the Estado? Save for a brief letter to João V, Juliana left behind no writings. Those descended from her could not hold on to their lands after the loss of Mughal power but held on to stories about her instead. Of her own parentage and origins, little 
is known. The stories that people write about her hold some aspect of her, but allow authors of her life to place onto her their own ambitions and desires. And the further away one moves from the past, the more extraordinary Juliana seems, for her prominence and for the many worlds she was able to inhabit. Yet, perhaps what is most extraordinary about Juliana is that she was by no means extraordinary in the syncretic landscape of Mughal India. 
Copyright of Journal of World History is the property of University of Hawaii Press and its content may not be copied or emailed to multiple sites or posted to a listserv without the copyright holder's express written permission. However, users may print, download, or email articles for individual use. 